$34: 1076$

<原 著 $>$

劇症肝炎患者血清の胆汁分泌機構におよぼす影響

福本 陽平 新開 泰司 沖田 極 竹本 忠良*

Robin D Hughes Christopher D Gove Roger Williams**

要 旨：劇症肝炎患者の血中に蓄積する中等大分子量の中毒性物質か，脳細胞膜の $\mathrm{Na}^{+}, \mathrm{K}^{+}$. ATPase 活性や, 白血球細胞の $\mathrm{Na}^{+}$の移動を阻害することが報告されている. 一方, 胆汁分泌 機構に扣ける肝細胞膜 $\mathrm{Na}^{+}, \mathrm{K}^{+}$-ATPase の役割について, 最近では $\mathrm{Na}^{+}$と胆汁酸の共輸送と いら観点から，胆汁酸の肝での移送に関与していると推察されるようになった。そこで，本報 では昏睡期の劇症肝炎患者血清より, 細胞膜 $\mathrm{Na}^{+}, \mathrm{K}^{+}$-ATPase 活性を低下させる物質を抽出 し，ラット門脈内に持続的に投与することによって，胆汁分必に与える影響を検討した。その 結果, ラットの胆汁分泌量は減少傾向を示し, 胆汁中への胆汁酸の排泄は対照群に比べ有意に 低下した. これらの事実は, 肝細胞膜 $\mathrm{Na}^{+}, \mathrm{K}^{+}$-ATPase がむしろ胆汁中への胆汁酸の分泌に介 在するという説を支持する結果となった。

索引用語： 胆汁分泌胆汁酸 劇症肝炎 $\mathrm{Na}^{+}, \mathrm{K}^{+}$-ATPase

はじめに

劇症肝炎患者の主な死因である脳浮腫が，脳細胞膜 における $\mathrm{Na}^{+}, \mathrm{K}^{+}$-ATPase 活性の阻害による $\mathrm{Na}^{+}$の 蓄積に起因すると推測され Williams らは,すでに昏睡期の劇症肝资患者血中に含 まれる中毒性物質が，ヒトの白血球細胞の $\mathrm{Na}^{+}$の移送 や3， ラット脳細胞膜の $\mathrm{Na}^{+}, \mathrm{K}^{+}$-ATPase 活性を阻害 することを報告してきだ．

一方, 肝細胞膜の $\mathrm{Na}^{+}, \mathrm{K}^{+}$-ATPase 活性の局在につ いては，現在なお議論の残るところであるが，肝細胞 への胆汁酸のとりこみは, $\mathrm{Na}^{+}$と共輸送によって流入 すると考光られることから，肝細胞の $\mathrm{Na}^{+}, \mathrm{K}^{+}$. ATPase は，むしろ胆汁酸の移送に介在するのではな いかと推察されるようになっだ.6.

本報では，この点をさらに明らかにする目的から， ヒト白血球細胞やラット脳細胞膜の $\mathrm{Na}^{+}, \mathrm{K}^{+}$. ATPase 活性を阻害する血清成分を既報の方法によ $\eta^{3,4)}$ ，昏睡期の劇症肝炎患者血清より抽出し，大量に ラットの門脈より持続的に注入して, 胆汁分必和よび 胆开中への胆汁酸排泄における影響を検討した．さら に，この抽出成分を, Sephadex G-25により分画し， 同様の方法によって投与することにより，あわせて胆

- 山口大学第 1 内科

** Liver Unit, King's College Hospital 〈受付日60年10月31日 $>$
汁中への胆汁酸分泌に対する影響について検索を加え た.

\section{実験方法}

対象は halothane による薬剤性の劇店肝资で死亡 した昏睡度V度の患者(症例 1 )血清を, Amicon PE10 膜を用いて窒素ガスにより ultrafiltration (Amicon model 402) を行い，分子量10,000daltons 以下の血清 成分を抽出した。この抽出成分を $15 \mathrm{~m} l$ ずつ凍結し，た だちに凍結・乾燥を行った（Freeze Mobile 6, Virtis Ltd). 一方, 正常人 6 名から採取した血清をプールし， 同様の方法により抽出して，対照検体とした。 これら の検体は実験直前まで, $-20^{\circ} \mathrm{C}$ 以下に保存した。抽出し た患者血清と正常人血清はともに 6 検体ずつ用意し，

ラット12匹を用いて検討した。

さらに, paracetamolによる劇症肝炎で死亡した昏 睡度 $\mathrm{V}$ 度の 3 名の患者(症例 2，3，4)血清を，别々 に同様の方法により分離, 抽出して保存し，ラット3 匹に投与した。これらの実験結果は，症例 1 の結果と 合わせて検索を行った。

また，ultrafiltration 後の血清成分を，さらにSephadex G-25 (Pharmacia Ltd) によるカラムクロ トダラフィーで分画し, $\mathrm{Na}^{+}, \mathrm{K}^{+}$-ATPase 活性阻害作 用が最もつよいことを確認している3,4，2 分画を動物 実験に用いた，対象血清は，前出の 4 名の劇症肝炎患 者とプールした正常人血清の 8 検体である。 
ultrafiltration後の血清成分は各々 $15 \mathrm{~m} l$ を $\mathrm{Se}$ phadex G-25カラム（内径 $2.5 \mathrm{~cm}$, 高さ80cm) にかけ, $0.1 \mathrm{~mol} \mathrm{NH}_{4} \mathrm{HCO}_{3}$ 緩衙液 ( $\mathrm{pH} 7.9$ )を用いて, 溶出 液を $5 \mathrm{~m} l$ ずつ採取した。分析は冷室で行い，吸光度は $205 \mathrm{~nm}$ と254nm で吸光度曲線を描出した。吸光度曲線 から得られた各々の分画は，フンモニゥムイオンを除 くため， 2 回ずつ凍結・乾燥をくり返し $-20^{\circ} \mathrm{C}$ 以下で 実験直前まで保存した。実験には tube No. 74, 75, 76 の No. 5分画と tube No. 105, 106, 107の No. 7分画 を使用し，患者 4 名と正常人 4 検体から分画した合計 16検体をラット16匹に投与して実験を行った。

胆计分泌に抽るこれらの血清成分の影䩧について は，Wistar 系雄性ラット（250～300g）を用いて，以 下の方法により検討した。ラットは，実験前に約 8 時 間絶食し，办のみを投与した。 Pentobarbital (50mg/

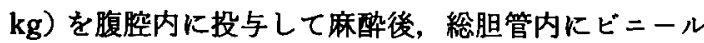
チューブを充分深く捜入し，一時クリップにて閉腹し た．胆汁分泌量が安定した後，10分間毎に90分目まで 胆计を採取した。採取開始から30分目に再び開腹し， 腸間膜静脈内へすばやくカニューレを挿入し，腹部を 䋖合閉腹した。このカニューレより，自動注入器を用 いて各々の血清成分の注入を行った，凍結，晥燥状態 で保存したそれぞれの検体は注入直前に生食 $1.8 \mathrm{~m} l$ で溶解し， $55 \mu l /$ 分 $(1.65 \mathrm{~m} l / 30$ 分) のゆっくりした速 度で，30分間持続的に投与した．採取した胆汁は，胆 汁量を計湘した後にー200 $\mathrm{C}$ 以下に凍結し，あとで胆汁 中の胆计酸（醭素法一ステログノスト $3 \alpha$ ），ナトリゥ ム，カリウム (炎色反応) 量を測定した。

\section{結 果}

まず，劇症肝炎患者症例 1 およ゙正常人の血清から 得られた，中等大分子量の血清成分をラット門脈内に 持続投与した結果，正常血清成分投与群（正常群）に くらべ，患者血清成分投与群（患者群）で，胆汁分泌 量は (Fig. 1)，血清成分投与開始後より低下する傾向 を示し，投与終了後の10分目では，正常群に比して有 意の差をむって低下した，また，その後の患者群の胆 汁分泌量は徐々に増加した。しかしながら，門脈内投 与前後の胆汁量との間には差は認められなかった。胆 汁中への胆汁酸の排泄量は（Fig. 2)，血清成分投与開 始啳の 20 分, 30 分目之，投与終了後の10分，30分目で, 患者群では正常群にくらべて有意の差をもって低下し た。しかし，胆汁中胆汁酸濃度は (Table 1)，患者群 では正常群より低い值を示したが，有意の差はみられ なかった。一方，胆汁中の $\mathrm{Na}^{+}$，および $\mathrm{K}^{+}$排泄量は，

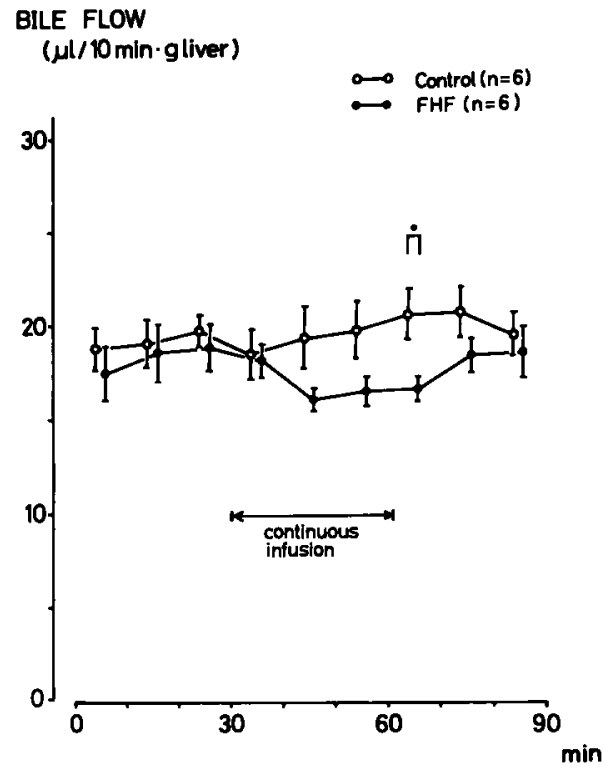

Fig. 1 The effect of fulminant hepatic failure (FHF) serum on rat hepatic bile flow. Each point represents the mean \pm S.E.. $* ; p<0.05$ compared to normal serum.

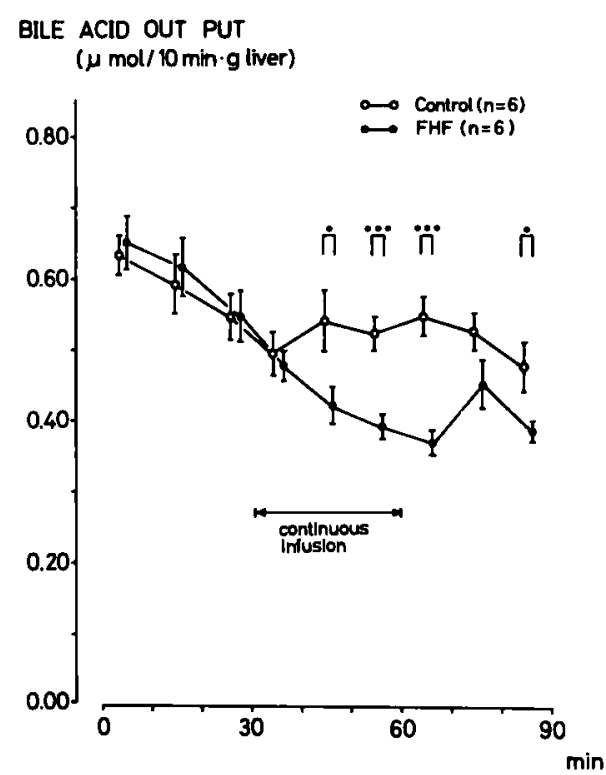

Fig. 2 The effect of FHF serum on rat bile acid output in bile. Each point represents the mean \pm S.E.. *; $p<0.05, * * ; p<0.01$ and $\cdots * ; p<0.001$ compared to normal serum.

患者群で $\mathrm{Na}^{+}$が門脈内投与30分目に, $\mathrm{K}^{+}$は投与終了後 10分目に一時的に低下したが，濃度は(Table 1)いず 
Table 1 Changes of the levels of bile acid, sodium and potassium in bile in the administration of serum ultrafiltrates $(<10,000)$ from normal control and FHF patients.

\begin{tabular}{|c|c|c|c|c|c|c|c|c|c|}
\hline$\underset{(\min )}{\text { Sampling Time }}$ & $0-10$ & $10-20$ & 20-30 & $30-40$ & $40-50$ & $50-60$ & $60-70$ & $70-800$ & $80-90$ \\
\hline \multicolumn{10}{|c|}{ Bile Acid Concentration ( $\mathrm{m} \mathrm{mol} / \mathrm{l}$ ) } \\
\hline Control $(n=6)$ & $33.7 \pm 1.2$ & $30.6 \pm 1.6$ & $28.0 \pm 1.0$ & $27.0 \pm 1.9$ & $27.9 \pm 2.2$ & $26.9 \pm 1.7$ & $27.1 \pm 2.2$ & $25.3 \pm 1.3$ & $24.5 \pm 2.0$ \\
\hline FHF $1 \#(n=6)$ & $37.9 \pm 3.3$ & $33.6 \pm 2.9$ & $29.1 \pm 1.3$ & $26.5 \pm 1.5$ & $26.6 \pm 1.8$ & $24.0 \pm 1.1$ & $22.9 \pm 1.5$ & $24.3 \pm 2.2$ & $21.3 \pm 1.7$ \\
\hline FHF $2 \# \#(n=4)$ & $32.8 \pm 1.8$ & $31.3 \pm 1.2$ & $28.5 \pm 0.9$ & $25.6 \pm 0.6$ & $24.0 \pm 1.2$ & $22.3 \pm 1.2$ & $21.3 \pm 1.2$ & $20.8 \pm 1.5$ & $20.2 \pm 0.7$ \\
\hline \multicolumn{10}{|c|}{$\mathrm{Na}^{+}$Out Put $(\mu \mathrm{mol} / 10 \mathrm{~min} \cdot \mathrm{g}$ liver $)$} \\
\hline Control $(n=6)$ & $3.08 \pm 0.14$ & $3.09 \pm 0.15$ & $3.09 \pm 0.17$ & $2.94 \pm 0.19$ & $3.11 \pm 0.22$ & $3.21 \pm 0.247$ & $3.36 \pm 0.22$ & $3.36 \pm 0.18$ & $3.15 \pm 0.15$ \\
\hline FHF $1 \#(n=6)$ & $2.84 \pm 0.16$ & $3.03 \pm 0.22$ & $3.03 \pm 0.22$ & $2.95 \pm 0.14$ & $2.65 \pm 0.11$ & $2.73 \pm 0.13$ & $2.73 \pm 0.11$ & $3.03 \pm 0.22$ & $3.08 \pm 0.23$ \\
\hline FHF 2\#\#(n=4) & $3.16 \pm 0.15$ & $3.12 \pm 0.08$ & $3.09 \pm 0.11$ & $2.89 \pm 0.14$ & $2.89 \pm 0.17$ & $2.94 \pm 0.10$ & $2.95 \pm 0.08$ & $3.03 \pm 0.04$ & $3.14 \pm 0.11$ \\
\hline \multicolumn{10}{|c|}{$\mathrm{Na}^{+}$Concentration ( $\mathrm{m} \mathrm{mol} / l$ ) } \\
\hline Control $(n=6)$ & $163.7 \pm 5.0$ & $159.8 \pm 3.6$ & $158.0 \pm 2.4$ & $158.2 \pm 1.8$ & $159.8 \pm 2.8$ & $162.0 \pm 3.3$ & $161.2 \pm 2.6$ & $160.5 \pm 1.6$ & $160.6 \pm 2.2$ \\
\hline FHF 1\# $(n=6)$ & $161.9 \pm 2.4$ & $161.5 \pm 2.6$ & $159.8 \pm 3.1$ & $161.2 \pm 1.6$ & $165.2 \pm 1.8$ & $165.2 \pm 1.4$ & $164.5 \pm 2.0$ & $164.7 \pm 2.3$ & $163.8 \pm 2.3$ \\
\hline FHF 2\#\# $(n=4)$ & $159.4 \pm 1.6$ & $159.4 \pm 1.6$ & $159.2 \pm 0.7$ & $160.3 \pm 1.1$ & $163.8 \pm 1.4$ & $165.3 \pm 1.7$ & $167.6 \pm 2.7$ & $163.0 \pm 1.4$ & $163.2 \pm 0.5$ \\
\hline \multicolumn{10}{|c|}{$\mathrm{K}^{+}$Out Put ( $\mu \mathrm{mol} / 10 \mathrm{~min} \cdot \mathrm{g}$ liver) } \\
\hline $\operatorname{Control}(n=6)$ & $0.103 \pm 0.005$ & $0.110 \pm 0.007$ & $0.113 \pm 0.007$ & $0.107 \pm 0.008$ & $0.115 \pm 0.009$ & $0.115 \pm 0.010$ & $0.119 \pm 0.0097$. & $0.127 \pm 0.011$ & $0.120 \pm 0.005$ \\
\hline FHF $1 \#(n=6)$ & $0.094 \pm 0.004$ & $0.108 \pm 0.007$ & $0.114 \pm 0.010$ & $0.107 \pm 0.007$ & $0.096 \pm 0.002$ & $0.097 \pm 0.003$ & $0.096 \pm 0.002$ & $0.108 \pm 0.007$ & $0.108 \pm 0.007$ \\
\hline FHF $2 \# \#(n=4)$ & $0.113 \pm 0.008$ & $0.115 \pm 0.005$ & $0.113 \pm 0.007$ & $0.104 \pm 0.008$ & $0.101 \pm 0.009$ & $0.097 \pm 0.006$ & $0.097 \pm 0.005$ & $0.101 \pm 0.005$ & $0.105 \pm 0.006$ \\
\hline \multicolumn{10}{|c|}{$\mathrm{K}^{+}$Concentration $(\mathrm{m} \mathrm{mol} / l)$} \\
\hline Control $(n=6)$ & $5.46 \pm 0.26$ & $5.68 \pm 0.22$ & $5.76 \pm 0.20$ & $5.76 \pm 0.29$ & $5.86 \pm 0.27$ & $5.80 \pm 0.21$ & $5.75 \pm 0.12$ & $6.03 \pm 0.29$ & $6.11 \pm 0.22$ \\
\hline FHF $1 \#(n=6)$ & $5.70 \pm 0.12$ & $5.86 \pm 0.11$ & $5.92 \pm 0.14$ & $5.79 \pm 0.15$ & $5.67 \pm 0.19$ & $5.47 \pm 0.22$ & $5.51 \pm 0.24$ & $5.42 \pm 0.22$ & $5.44 \pm 0.19$ \\
\hline FHF $2 \#(n=4)$ & $5.35 \pm 0.23$ & $5.76 \pm 0.26$ & $6.00 \pm 0.31$ & $5.96 \pm 0.16$ & $6.01 \pm 0.14$ & $5.90 \pm 0.18$ & $5.86 \pm 0.20$ & $5.90 \pm 0.26$ & $5.76 \pm 0.23$ \\
\hline
\end{tabular}

FHF 1\#: FHF patient Case 1

FHF 2\#\#: FHF patients Case 1, 2, 3 and 4

-Statistical significanse $p<0.05$

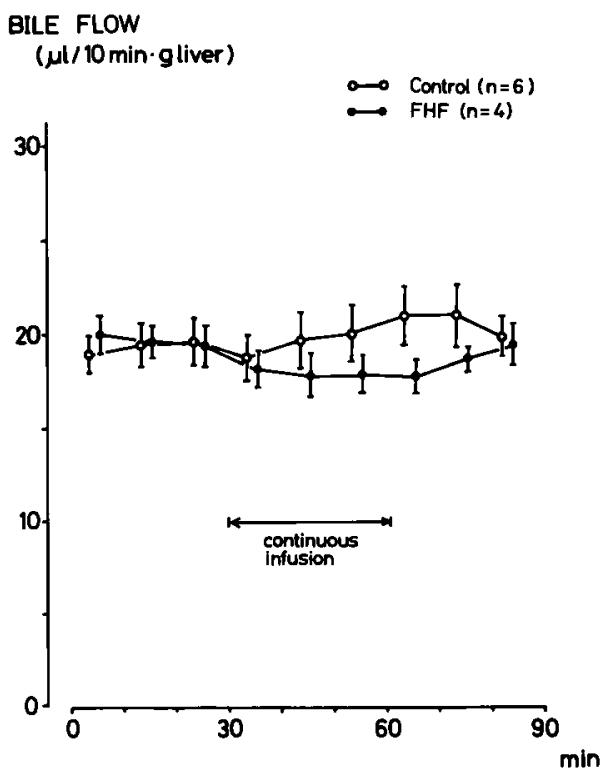

Fig. 3 The effect of FHF serums on rat hepatic bile flow. Each point represents the mean \pm S.E..

れも正常群との間で有意の差を示さなかった。

次に，症例 $2 ， 3 ， 4$ の患者血清投与実験での成績に， 症例 1 の成績（平均值）を合せて，4 例の劇症肝炎患
BLLE ACID OUT PUT ( $\mu \mathrm{mol} / 10 \mathrm{~min} \cdot \mathrm{g}$ liver)

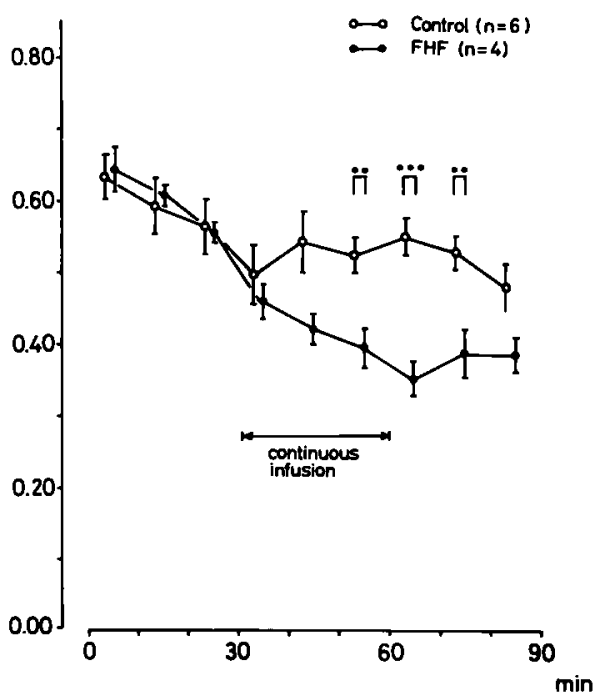

Fig. 4 The effect of FHF serums on rat bile acid output in bile. Each point represents the mean \pm S.E.. " ; $p<0.01$ and ***; $p<0.001$ compared to normal serum.

者群で検討すると，胆汁分泌量 (Fig. 3)，胆汁中への 胆汁酸排泄量(Fig. 4)は，症例 1 での結果とほぼ同様 

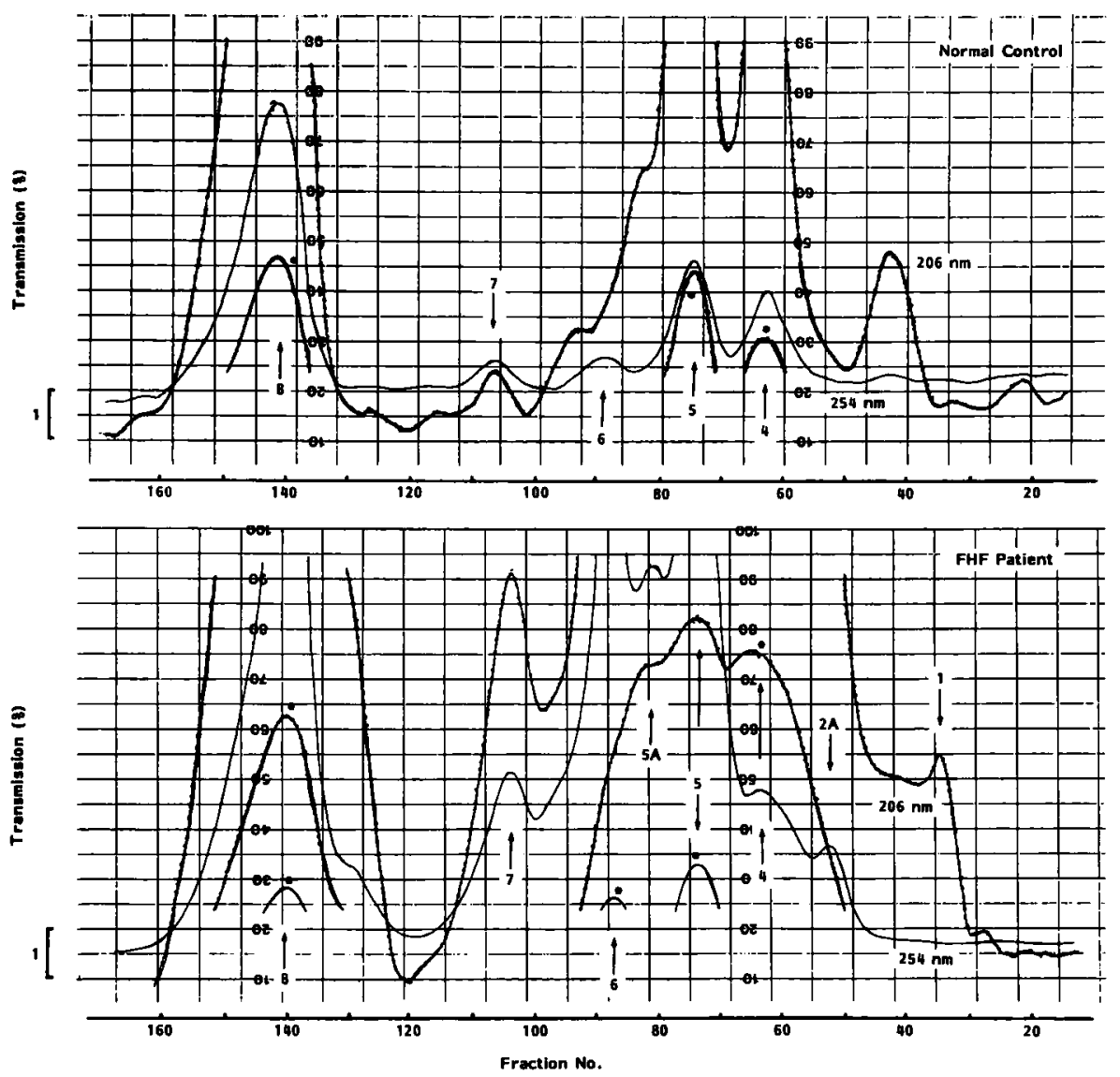

Fig. 5 Elution profiles of serum ultrafiltrate $(<10,000$ daltons $)$ on Sephadex G. 25 shown as the \% transmission of light in normal control (upper) and FHF patient (lower). Star means five fold of \% transmission comparing to basal \% transmisson.

の変化がみられた。すなわち, 胆汁分泌量には有意の 差は認められないものの, 患者群では低下傾向がみら れ，一方，胆汁中への胆汁酸分泌は，血清成分投与開 始後の 30 分目と，投与終了後の 10 分，20分目に，患者 群では正常群にくらべて有意の差をすって低下した。 胆汁中胆汁酸浱度も患者群で低值を示したが有意差は なく，胆计中 $\mathrm{Na}^{+}, \mathrm{K}^{+}$量は，排泄量および浱度のいず れにも差はみられなかった (Table 1).

分子量10,000daltons 以下の血清成分を, Sephadex G-25で分画すると，Fig. 5に示すようなピークが認め られた。これらのピークのらちNo. 4, 5, 5A，6，7は正 常群に比して患者群で著明に増加した。

これらの分画の内 No. 5 と No. 7分画を，同様の方 法で,門脈から肝内に注入した結果, No. $5 お$ よびNo. 7はともに，胆汁分必量は（Fig. 6,Fig. 8)，患者群で
正常群に比べて有意の低下がみられた。しかし，門脈 内投与前後の分泌量では, 有意の変化を示さなかった. 一方, 胆汁中への胆汁酸分泌量は(Fig. 7, Fig. 9)，い ずれも，血清成分の投与開始後20分，30分目と，投与 終了後の 10 分目に, 患者群では正常群に比して, 有意 の差をむって低下した。しかし，胆汁中の胆汁酸濃度 には(Table 2)，差はみられなかった。また, $\mathrm{Na}^{+}, \mathrm{K}^{+}$ 量は, 分画 No. 5 の投与開始後 30 分目に, 分画 No. 7 の 投与後半之終了後10分目で，患者群の低下が認められ たが，濃度には（Table 2)，差はなかった。

分画No. 5 と No. 7では門脈内投与後の胆汁酸排泄 曲線が，正常群および患者群でも異ったパターンを示 した. 分画No.7では，正常群，患者群ともに胆汁酸分 泌は上昇する傾向がみられた。 


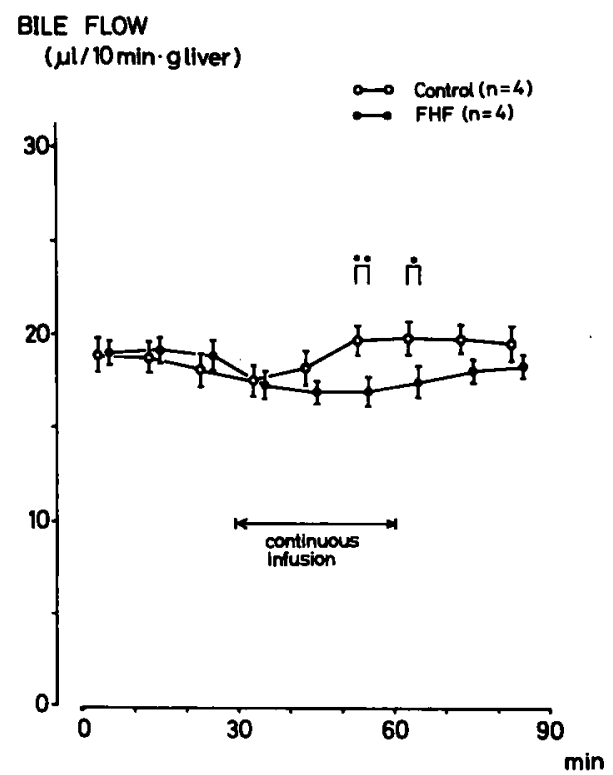

Fig. 6 The effect of FHF peak No 5 chromatographed on Sephadex G-25 from serum ultrafiltrate on rat hepatic bile flow. Each point represents mean \pm S.E.. *; $p<0.05$ and **; $p<$ 0.01 compared to normal serum.

BILE ACID OUT PUT

( $\mu \mathrm{mol} / 10 \mathrm{~min} \cdot \mathrm{g}$ liver)

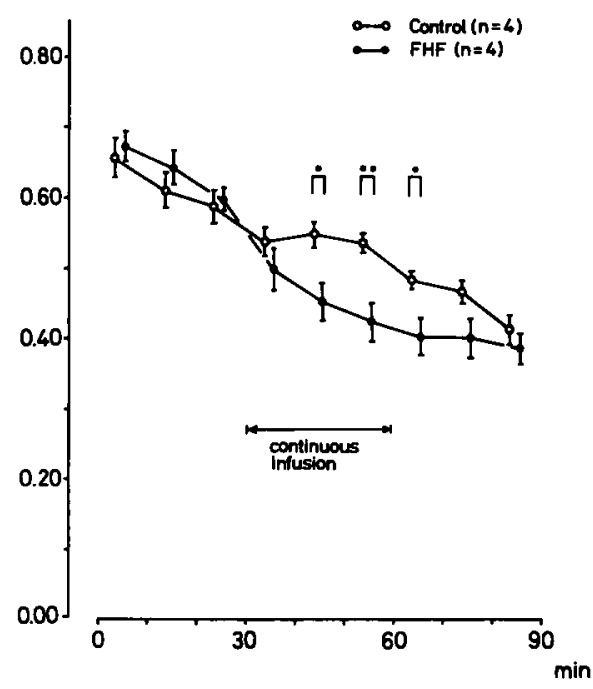

Fig. 7 The effect of FHF peak No 5 chromatographed on Sephadex G-25 from serum ultrafiltrate on rat bile acid output in bile. Each point represents the mean \pm S.E.. : $p<0.05$ and **; $p<0.01$ compared to normal serum.

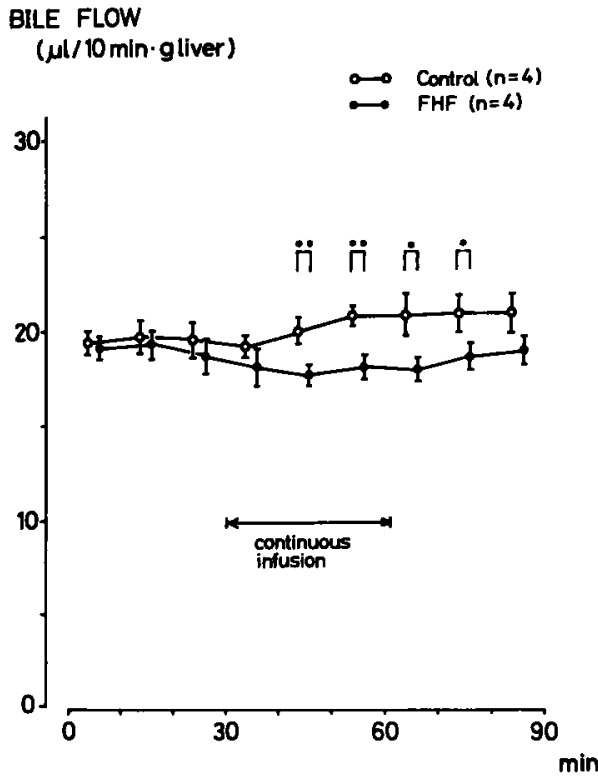

Fig. 8 The effect of FHF peak No 7 chromatographed on Sephadex G.25 from serum ultrafiltrate on rat hepatic bile flow. Each point represents mean \pm S.E.. *; $p<0.05$ and **; $p<$ 0.01 compared to normal serum.

BILE ACID OUT PUT

( $\mu \mathrm{mol} / 10 \mathrm{~min} \cdot \mathrm{g}$ liver)

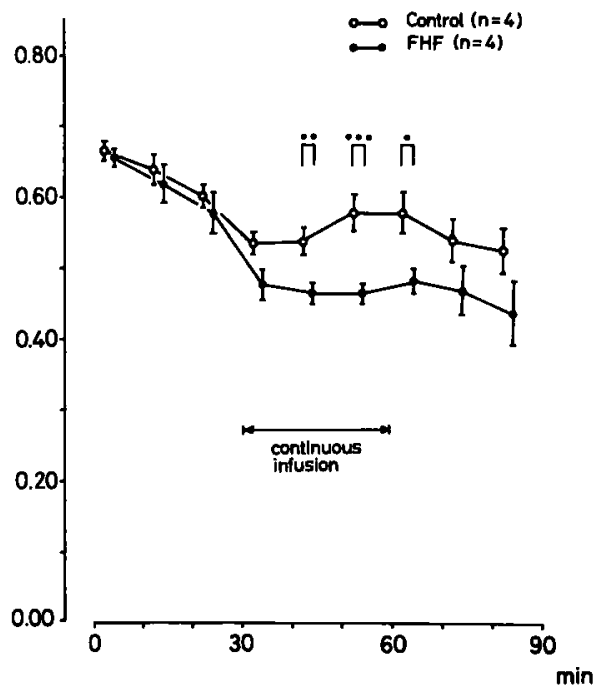

Fig. 9 The effect of FHF peak No 7 chromatographed on Sephadex G-25 from serum ultrafiltrate on rat bile acid output in bile. Each point represents the mean \pm S.E.. * ; p <0.05, * ; $\mathrm{p}<0.01$ and ${ }^{* * *} ; \mathrm{p}<0.001$ compared to normal serum. 
Table 2 Changes of the levels of bile acid, sodium and potassium in bile in the administration of peak No. 5 and No. 7 chromatographed on Sephadex G-25 from serum ultrafiltrates of normal controls and FHF patients.

\begin{tabular}{|c|c|c|c|c|c|c|c|c|c|}
\hline $\begin{array}{l}\text { Sampling Time } \\
\text { (min) }\end{array}$ & $0-10$ & $10-20$ & $20-30$ & $30-40$ & $40-50$ & $50-60$ & $60-70$ & $70-80$ & $80-90$ \\
\hline \multicolumn{10}{|c|}{ Bile Acid Concentration ( $\mathrm{m} \mathrm{mol} / l$ ) } \\
\hline Peak $5-N \#(n=4)$ & $34.6 \pm 0.4$ & $32.3 \pm 0.6$ & $32.3 \pm 0.9$ & $30.4 \pm 0.6$ & $29.6 \pm 0.5$ & $26.9 \pm 0.5$ & $24.2 \pm 0.9$ & $23.5 \pm 1.2$ & $21.4 \pm 1.4$ \\
\hline Peak 5-P $\#(n=4)$ & $35.4 \pm 1.8$ & $33.4 \pm 1.4$ & $31.3 \pm 0.5$ & $28.4 \pm 1.1$ & $26.4 \pm 1.4$ & $24.8 \pm 1.4$ & $23.4 \pm 1.3$ & $22.4 \pm 1.4$ & $20.9 \pm 1.4$ \\
\hline Peak $7-N \#(n=4)$ & $34.6 \pm 1.6$ & $32.6 \pm 1.3$ & $30.7 \pm 1.0$ & $27.9 \pm 1.0$ & $27.0 \pm 0.8$ & $27.9 \pm 1.2$ & $27.8 \pm 1.1$ & $25.8 \pm 0.5$ & $24.9 \pm 0.7$ \\
\hline Peak 7-P $\sharp(n=4)$ & $34.7 \pm 1.3$ & $32.2 \pm 1.0$ & $31.3 \pm 0.5$ & $26.4 \pm 0.9$ & $26.3 \pm 0.5$ & $25.7 \pm 0.5$ & $26.6 \pm 0.6$ & $22.9 \pm 2.4$ & $22.9 \pm 2.4$ \\
\hline \multicolumn{10}{|c|}{$\mathrm{Na}^{+}$Out Put $(\mu \mathrm{mol} / 10 \mathrm{~min} \cdot \mathrm{g}$ liver $)$} \\
\hline Peak 5-N\#(n=4) & $3.07 \pm 0.14$ & $3.03 \pm 0.09$ & $2.90 \pm 0.13$ & $2.80 \pm 0.13$ & $2.91 \pm 0.14$ & $3.10 \pm 0.077$ & $3.14 \pm 0.11$ & $3.13 \pm 0.11$ & $3.08 \pm 0.09$ \\
\hline Peak 5-P\#(n=4) & $3.11 \pm 0.05$ & $3.07 \pm 0.08$ & $3.07 \pm 0.10$ & $2.80 \pm 0.08$ & $2.75 \pm 0.06$ & $2.74 \pm 0.04$ & $2.83 \pm 0.07$ & $2.92 \pm 0.04$ & $2.91 \pm 0.06$ \\
\hline Peak $7-N \#(n=4)$ & $3.10 \pm 0.06$ & $3.13 \pm 0.13$ & $3.13 \pm 0.12$ & $3.00 \pm 0.04$ & $3.12 \pm 0.057 \ldots$ & $3.28 \pm 0.037$ & $3.31 \pm 0.04$ & $3.27 \pm 0.13$ & $3.30 \pm 0.15$ \\
\hline Peak 7 -P $\#(n=4)$ & $3.04 \pm 0.11$ & $3.09 \pm 0.12$ & $3.00 \pm 0.11$ & $2.86 \pm 0.11$ & $2.79 \pm 0.05]^{\circ}$ & $2.86 \pm 0.09$ & $2.87 \pm 0.07$ & $2.94 \pm 0.09$ & $2.96 \pm 0.07$ \\
\hline \multicolumn{10}{|c|}{$\mathrm{Na}^{+}$Concentration $(\mathrm{m} \mathrm{mol} / l)$} \\
\hline Peak $5-\mathrm{N} \#(n=4)$ & $162.3 \pm 1.3$ & $160.8 \pm 1.9$ & $160.0 \pm 2.1$ & $158.5 \pm 2.3$ & $157.8 \pm 1.7$ & $156.5 \pm 1.3$ & $157.5 \pm 0.9$ & $157.8 \pm 1.3$ & $156.5 \pm 1.7$ \\
\hline Peak 5-P $\#(n=4)$ & $163.5 \pm 1.4$ & $159.8 \pm 1.0$ & $161.8 \pm 0.9$ & $160.8 \pm 0.5$ & $161.3 \pm 0.6$ & $159.0 \pm 0.4$ & $160.5 \pm 1.0$ & $160.3 \pm 1.6$ & $157.8 \pm 0.8$ \\
\hline Peak $7-N \#(n=4)$ & $160.5 \pm 2.2$ & $159.5 \pm 1.0$ & $160.8 \pm 1.3$ & $156.8 \pm 1.1$ & $156.5 \pm 1.9$ & $158.0 \pm 0.6$ & $159.0 \pm 2.2$ & $157.0 \pm 1.5$ & $157.8 \pm 2.8$ \\
\hline Peak 7-P\#(n=4) & $160.0 \pm 0.7$ & $160.8 \pm 1.3$ & $160.5 \pm 1.3$ & $158.5 \pm 1.5$ & $158.3 \pm 0.6$ & $158.5 \pm 1.2$ & $158.3 \pm 1.4$ & $157.8 \pm 0.5$ & $156.5 \pm 0.9$ \\
\hline \multicolumn{10}{|c|}{$\mathrm{K}^{+}$Out Put $(\mu \mathrm{mol} / 10 \mathrm{~min} \cdot \mathrm{g}$ liver $)$} \\
\hline Peak $5-N \#(n=4)$ & $0.104 \pm 0.006$ & $0.105 \pm 0.005$ & $0.101 \pm 0.006$ & $0.100 \pm 0.007$ & $0.103 \pm 0.004$ & $0.115 \pm 0.0057$. & $0.116 \pm 0.008$ & $0.117 \pm 0.008$ & $0.116 \pm 0.007$ \\
\hline Peak 5-P $\#(n=4)$ & $0.102 \pm 0.004$ & $0.105 \pm 0.005$ & $0.108 \pm 0.005$ & $0.100 \pm 0.005$ & $0.099 \pm 0.003$ & $0.094 \pm 0.006$ & $0.104 \pm 0.014$ & $0.101 \pm 0.008$ & $0.103 \pm 0.006$ \\
\hline Peak $7-N \#(n=4)$ & $0.103 \pm 0.006$ & $0.108 \pm 0.010$ & $0.111 \pm 0.010$ & $0.109 \pm 0.007$ & $0.119 \pm 0.007$ & $0.126 \pm 0.006$ & $0.127 \pm 0.0067$ & $0.129 \pm 0.008$ & $0.130 \pm 0.010$ \\
\hline Peak 7-P\#(n=4) & $0.105 \pm 0.001$ & $0.110 \pm 0.002$ & $0.110 \pm 0.002$ & $0.105 \pm 0.004$ & $0.104 \pm 0.002$ & $0.106 \pm 0.001]^{\circ}$ & $0.106 \pm 0.002$ & $0.110 \pm 0.003$ & $0.111 \pm 0.004$ \\
\hline \multicolumn{10}{|c|}{$\mathrm{K}^{+}$Concentration $(\mathrm{m} \mathrm{mol} / l)$} \\
\hline Peak $5-N \#(n=4)$ & $5.47 \pm 0.11$ & $5.55 \pm 0.15$ & $5.52 \pm 0.17$ & $5.65 \pm 0.22$ & $5.80 \pm 0.22$ & $5.80 \pm 0.20$ & $5.80 \pm 0.17$ & $5.87 \pm 0.18$ & $5.87 \pm 0.18$ \\
\hline Peak 5-P\#(n=4) & $5.40 \pm 0.27$ & $5.47 \pm 0.25$ & $5.70 \pm 0.27$ & $5.75 \pm 0.33$ & $5.77 \pm 0.37$ & $5.55 \pm 0.41$ & $5.55 \pm 0.38$ & $5.55 \pm 0.34$ & $5.60 \pm 0.38$ \\
\hline Peak $7-N \#(n=4)$ & $5.35 \pm 0.25$ & $5.47 \pm 0.32$ & $5.57 \pm 0.21$ & $5.67 \pm 0.25$ & $5.95 \pm 0.23$ & $6.05 \pm 0.25$ & $6.10 \pm 0.25$ & $6.17 \pm 0.34$ & $6.20 \pm 0.33$ \\
\hline Peak 7-P\#(n=4) & $5.52 \pm 0.19$ & $5.75 \pm 0.26$ & $5.81 \pm 0.15$ & $5.85 \pm 0.21$ & $5.91 \pm 0.16$ & $5.85 \pm 0.15$ & $5.85 \pm 0.20$ & $5.92 \pm 0.15$ & $5.87 \pm 0.18$ \\
\hline
\end{tabular}

$\mathrm{N} \#$ : Normal control

$P \#$ : FHF patients

*Statistical significance $\mathrm{p}<0.05$

" Statistical significance $p<0.01$

\section{考案}

共同研究者の Williams らは, すでに, 昏睡期の劇症 肝炎患者血清に含まれる成分により，正常人白血球細 胞における $\mathrm{Na}^{+}$の移動が阻害されこの血清を活性炭 カラムに通すと，その阻害作用は減弱することを報告 している3). また, 正常ラット脳細胞膜のウフバイン感 受性 $\mathrm{Na}^{+}, \mathrm{K}^{+}$-ATPase 活性が, 昏睡期の同患者の雮脊 髄液や血清によって低下することる認めている゙．さ らに, Amicon PE 10 膜で ultrafiltrateした分子量 10,000daltons 以下の胍症肝炎患者血清をSephadex G-25で分画した血清分画でも， $\mathrm{Na}^{+}$移動の阻害や， $\mathrm{Na}^{+}, \mathrm{K}^{+}$-ATPase 活性の低下作用のあることを発表 した ${ }^{3,4)}$.これらの成績は劇症肝炎患者の血中に蓄積す る中毒性物質の代謝面に与える影響の重要性を示す傍 証となった

本報では，胆计分泌機構の一端を解明しようといら 試みから, 細胞膜 $\mathrm{Na}^{+}, \mathrm{K}^{+}$-ATPase 活性を阻害する劇 症肝资患者血清を用いて，胆汁分泌機構に対する影響 についての検討を行った．患者血清からの中等大分子
量の物質の抽出は，Williams らの方法で行い，かつ同 実験施設を利用した。 Sephadex G-25で分画される ピークのらち，患者群で著明に上昇するNo. 3,4,5,7 は，いずれす白血球細胞での $\mathrm{Na}^{+}$の移動, 脳細胞膜 $\mathrm{Na}^{+}, \mathrm{K}^{+}$-ATPase 活性の阻害効果が認められてい $ろ^{3,4)}$. 最近の報告では，急性肝不全患者の血中で増加 する中毒性物質の分子量は1,000 1,500daltons であ るといわれ9, 実験動物における急性肝不全モデルで あ，1,000４,000daltons の物質が上昇しているとさ れている10.11). 本報で分画したピーク No. 3,4,5,7の 分子量は, ビタミン $B_{12}$ をカムにかけた Williams ら の実験結果から゙)，500〜1,500daltons であった。

今回の実験では，急性肝不全に近い状態を作る目的 で，注ラットの血液量に近い量の $15 \mathrm{~m} l$ の血清より 分画された成分を筫縮し，門脈から持続的に注入を 行った，また，門脈血流に対する影掣を考虑して，投 与した液量は極めて少く，投与速度も遅くした。 その 結果，いずれの動物実験においてる，胆汁への胆汁酸 の分必は，正常群に対して患者群で有意の差をるって 
低下した，胆汁量も一部の患者群では正常群に比して 有意の差をむって減少したが，門脈内投与前の基礎分 必量とは差がなく，分必量の低下にまでは至らなかっ た。これは，実験に用いたラットでは，肝のクッパー 細胞が正常に機能し，分泌量に差を示すほどの影䉪に までおよばなかったことが推測される，また，正常肝 における paracellular pathway からの分泌で代偵さ れることも考えられる。

肝細胞における胆汁酸や】ミノ酸，無機および有機 イオンのとり込み，排泄には，いくつかの仮説が示さ れているが5,12), 肝内とジヌンイド側の電気ボテンシャ ルか，肝内で負となることから，陽イオン性物質は肝 内に流入しやすく，陰イオン性物質は流入し難いとさ れている，そこで，胆汁酸す有機陰イオン性物質であ るので，その流入は $\mathrm{Na}^{+}$との共輸送で行われると考え られるよらになった ${ }^{12,13)}$ 。この輸送機構は, 当然 $\mathrm{Na}^{+}$ ポンブである $\mathrm{Na}^{+}, \mathrm{K}^{+}$-ATPase の影響をうけるため, 最近, この観点から改めて胆汁酸の移送と $\mathrm{Na}^{+}, \mathrm{K}^{+}$. ATPase との関連性が検討されている.

すでに, Keeffe らは ${ }^{14)}$, thyroid hormone phenobarbital, ethinylestradiol, propylene glycol ts どをラットに投与し，肝細胞膜 $\mathrm{Na}^{+}, \mathrm{K}^{+}$-ATPase 活性 と胆汁の胆汁酸非依存性分泌とを検討した。その結果, $\mathrm{Na}^{+}, \mathrm{K}^{+}$-ATPase 活性は胆汁酸非依存性分泌よりも， むしろ侤存性分泌との関連性が強いのではないかと推 測している。また，胆汁酸の腸管における吸収細胞て ある回腸細胞を用いた Wilson らの実験では ${ }^{15)}$ ， ラッ トの分離回腸細胞のグリココール酸のとり込みは，ウ アパインによる細胞膜 $\mathrm{Na}^{+}, \mathrm{K}^{+}$.ATPase 活性の阻害 の程度と平行して低下し, methyl predonisolon によ る $\mathrm{Na}^{+}, \mathrm{K}^{+}$-ATPase 活性の上昇とともに增加するこ とを発表した。ささらに，これには $\mathrm{Na}^{+}$の存在が必要で あった。

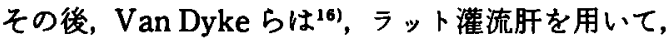
灌流液中のイオンを交換することにより， $\mathrm{Na}^{+}$とタウ 口コール酸依存性胆汁分泌との関連性を証明し，胆汁 酸依存性胆汁分泌には膜の $\mathrm{Na}^{+}, \mathrm{K}^{+}$-ATPase を介す る $\mathrm{Na}^{+}$の役割の重要性を指摘した。一方, 胆汁酸非依 存性胆计分泌には，直接的拉上び間接的にも bicarbonate が関与しているのではないかと述べている.

これらの報告は，いずれも肝細胞膜 $\mathrm{Na}^{+}, \mathrm{K}^{+}$. ATPase は, 胆计酸非俵存性胆汁分泌上りるむしろ胆 汁酸依存性分泌関与すると推湘するるのであるが， 本報における我々の実験成瞔も，患者血中に蓄積する
中毒性物質が, 肝細胞膜の $\mathrm{Na}^{+}, \mathrm{K}^{+}$-ATPase 活性を阻 害し，肝細胞での胆计酸のとり込みや移送を抑制した と考えれば非常につごらがよい。

これには，当然，肝細胞膜における $\mathrm{Na}^{+}, \mathrm{K}^{+}$. ATP ase 活性の局在が問題となるところで, sinusoidallateral 面にこの醅素活性が存在することが望ましい． 歴史的にはまず, canalicular 説が最初にだされたが， 最近では, sinusoidal-lateral 存在説を主張する Boyer 一派の実験成績が多くの支持を得ている17.18). 近ごろ 発表されたモノクロナール抗体を用いて行った canalicular 面局在説に対しても ${ }^{199}$ ，その後 Boyer $ら$ は反論を加えている20).

本報での実験結果から，劇症肝炎患者の血中に存在 する中等大の分子量を有する中毒性物質により，胆汁 中への胆汁酸の分泌が抑制されることが明らかとなっ た. 肝細胞における胆汁酸の分泌機構には，多くの問 題が残されており, 胆汁分泌に関する paracellular pathway の役割とともにその解明がいそがれる.

\section{結 論}

昏睡期の劇症肝炎患者血中に蓄積する中等大分子量 の物質を, ラッ卜門脈内に注入することにより，胆汁 中への胆汁酸の排泄が抑制された。このよらな劇症肝 炎患者の血清から抽出される中等大分子量の中毒性物 質は，細胞膜の $\mathrm{Na}^{+}, \mathrm{K}^{+}$-ATPase 活性を阻害すること から，肝細胞に拈ける胆汁酸の移送と，膜醭素 $\mathrm{Na}^{+}$， $\mathrm{K}^{+}$-ATPase の関連性が推測された。

本実験の大部分はR. Williamsの指導のもとに, King's College (London)で行った。ここにそれを明記し深謝する したいである.

\section{文 献}

1) Alan AN, Wilkinson SP, Poston $L$, et al: Intracellular electrolyte abnormalities in fulminant hepatic failure. Gastroenterology 72 : 914-917, 1977

2) Alan AN, Poston L, Wilkinson SP, et al: A study in vitro of the sodium pump in fulminant hepatic failure. Clin Sci and Mol Med 55 : 355 $-363,1978$

3) Sewell RB, Hughes RD, Poston $L$, et al : Effects of serum from patient with fulminant hepatic failure on leucocyte sodium transport. Clin Sci 63 : 237-242, 1982

4) Seda HWM, Hughes RD, Gove $C D$, et al: Inhibition of rat brain $\mathrm{Na}^{+}, \mathrm{K}^{+}$-ATPase activity 
by serum from patients with fulminant hepatic failure. Hepatology $4: 74-79,1984$

5) Boyer JL: New concepts of mechanisms of hepatocyte bile formation. Physiol Review 60 : 303-326, 1980

6) Erlinger $\mathrm{S}$ : Does $\mathrm{Na}^{+}, \mathrm{K}^{+}$-ATPase have any riole in bile formation?. Am J Physiol 243 : G243 -G247, 1982

7) Canalese J, Gimson AES, Davis $M$, et al: A controlled trial of dexamethasone and mannitol for the cerebral oedema of fulminant hepatic failure. Gut 23 : 625-629, 1982

8) Gimson AES, Ede R, Braude $S$, et al: Fulminant hepatic failure and artifical liver support. Gastroenterologia Japonica $17:$ 144-162, 1982

9) Lever HW, Klausmann J, Goubeaud G, et al : Middle molecules in the serum of patients and rats with liver failure. Influence of sorbent haemoperfusion. In : Artificial liver support, Edited by G Brunner, FW Schmidt. SpingerVerlag, New York, 1981, p96-102

10) Faguer P, Delorme ML, Denis J, et al : Demonstration of middle molecules in plasma and brain during experimental acute hepatic encephalopathy. Am Soc Artif Organs J 3 : 153-159, 1980

11) Bloch P, Delrome ML, Rapin JR, et al : Reversible modification of neurotransmitters of the brain in experimental acute hepatic coma. Surg Gynecol Obstet 146:551-558, 1978

12) Thalhammer $T$, Fuchs $R$, Deterlik $M$, et al: Hepatocellular electrolyte transport and bile secretion. In : Hepatology, Edited by $\mathrm{H}$ Brun- ner, H Thaler. Raven Press, New York, 1985, p319-327

13) Blitzer BL, Boyer JL: Cellular mechanism of bile formation. Gastroenterology 82 : 346-367, 1982

14) Keeffe EB, Scherschmidt BF, Blankenship NM, et al: Studies of relationships among bile flow, liver plasma membrane $\mathrm{Na}^{+}, \mathrm{K}^{+}$-ATPase and membrane microviscosity in the rat. $\mathrm{J}$ Clin Invest $64: 1590-1598,1979$

15) Wilson FA, Treanor LL: Studies of relationships among bile acid uptake, $\mathrm{Na}^{+}, \mathrm{K}^{+}$-ATPase, and $\mathrm{Na}^{+}$gradient in isolated cells from rat ileum. Gastroenterology $81: 54-60,1981$

16) Van Dyke RW, Stephens JE, Scherschmidt BF : Effects of ion substitution on bile acid-dependent and independent bile formation by rat liver. J Clin Invest $70: 505-517,1982$

17) Boyer JL, Allen RM, Ng OC: Biochemical separation of $\mathrm{Na}^{+}, \mathrm{K}^{+}$-ATPase from a "Purified" light dencity, "Canalicular"-enriched plasma membrane fraction from rat liver. Hepatology $3: 18-28,1983$

18) Klassen CD, Watkins JB: Mechanism of bile formation, hepatic uptake, and biliary excretion. Pharmacol Review 36:1-67, 1984

19) Schenk DB, Leffert HL: Monoclonal antibodies to rat $\mathrm{Na}^{+}, \mathrm{K}^{+}$-ATPase block enzynatic activity. Proc Natl Acad Sci USA 80 : $5281-5285,1983$

20) Blitzer BL, Boyer JL: Localization of $\mathrm{Na}^{+}$, $\mathrm{K}^{+}$-ATPase on the hepatocyte plasma membrane. Gastroenterology 87 : 1206-1210, 1984 


\title{
Effects of serum from patients with fulminant hepatic failure on bile flow
}

\author{
Yohei Fukumoto, Yasuji ShinkaI, Kiwamu OKita, Tadayoshi Takemoto*, \\ Robin D Hughes, Christopher D GOVE and Roger WILlIAMS**
}

Substances which inhibit the $\mathrm{Na}^{+}, \mathrm{K}^{+-A T P a s e}$ activity in rat brain cell membrane have been found out among toxins in the circulation of patient with fulminant hepatic failure (FHF). In this examination, the effect of middle molecular serum substances from FHF patients on bile secretion was evaluated using rat. Serum ultrafiltrates and elution peaks chromatographed on Sephadex G25 from ultrafiltrate of FHF patients were infused into rats portal vein. As a result, bile acid output in bile was reduced significantly as compared to normal control after administration of serum substances. More recently, it is strongly suggested that bile acid uptake into the hepatocyte is a coupled transport with sodium maintained by the $\mathrm{Na}+, \mathrm{K}+$-ATPase. Thus, the results in this study seem to support a hypothesis that $\mathrm{Na}^{+}, \mathrm{K}+$-ATPase play an important role in coupling transport of bile acid and resulting in the so-called bile acid-dependent bile flow.

* 1st Division, Department of Internal Medicine, Yamaguchi University School of Medicine (Ube)

** Liver Unit, King's College Hospital (London) 